TIPA. Travaux interdisciplinaires sur la parole et le langage

$27 \mid 2008$

Apprentissage et acquisition d'une langue seconde

\title{
La production des consonnes coronales en anglais par des apprenants francophones
}

Thèse dirigée par Noël Nguyen, soutenue le 19 septembre 2008

The production of coronal consonants in English by native French speakers.

\section{Stéphane Mortreux}

\section{(2) OpenEdition}

Journals

Édition électronique

URL : https://journals.openedition.org/tipa/396

DOI : 10.4000/tipa.396

ISSN : 2264-7082

Éditeur

Laboratoire Parole et Langage

Édition imprimée

Date de publication : 1 juin 2008

ISSN : 1621-0360

\section{Référence électronique}

Stéphane Mortreux, «La production des consonnes coronales en anglais par des apprenants

francophones », TIPA. Travaux interdisciplinaires sur la parole et le langage [En ligne], 27 | 2008, mis en ligne le 04 décembre 2012, consulté le 08 septembre 2021. URL : http://journals.openedition.org/tipa/ 396 ; DOI : https://doi.org/10.4000/tipa.396

Ce document a été généré automatiquement le 8 septembre 2021

\section{(c)}

La revue TIPA. Travaux interdisciplinaires sur la parole et le langage est mise à disposition selon les termes de la licence Creative Commons Attribution - Pas d'Utilisation Commerciale - Pas de Modification 4.0 International. 


\title{
La production des consonnes coronales en anglais par des apprenants francophones
}

Thèse dirigée par Noël Nguyen, soutenue le 19 septembre 2008

The production of coronal consonants in English by native French speakers.

\author{
Stéphane Mortreux
}

1 Notre travail de recherche porte sur la production des consonnes coronales anglaises / $t, d, n / p a r$ des apprenants francophones. Bien que ces phonèmes fassent partie du répertoire de l'anglais et du français, des différences infra-phonémiques se manifestent dans leur réalisation, au niveau du voisement et du lieu d'articulation des occlusives. Il est reconnu que les aspects phonétiques sont, parmi les nombreux aspects d'une langue, les plus difficiles d'acquisition dans l'apprentissage d'une L2.

2 Nous abordons, dans ce travail, l'acquisition de la phonologie de la langue maternelle, avant de nous concentrer sur l'acquisition d'une L2 chez les adultes. Au travers d'une étude acoustique et articulatoire, nous montrons qu'une production semblable à celle d'un locuteur natif est réalisée par les apprenants, qui ont une maitrise suffisamment grande de leur appareil articulatoire pour leur permettre de produire les sons de la L2 différemment de ceux de la L1.

Our research concentrates on the production of English coronal consonants /t, d, n/ by French speakers. Although these phonemes belong to the repertoire of both languages, they present sub-phonemic differences in their realization, as regards voicing and place of articulation. It is well-established that the phonetic aspect is, among all the aspects of a language, the most difficult to acquire in an L2.

4 We approach in this work the phonological acquisition of the first language, before focussing on the acquisition of an L2 by adult learners. Through an acoustic and 
articulatory study, we show that a production similar to a native speaker's one is realized by French learners, having a sufficiently great control on their articulatory system, which allows them to produce L2 sounds differently from those of the L1.

\section{INDEX}

Mots-clés : acoustique, palatographie, production, consonnes anglaises et françaises, acquisition d'une L2, plasticité du cerveau, contrôle moteur

Keywords : acoustics, palatography, production, English and French consonants, L2 acquisition, brain plasticity, motor control 